\title{
The Cutlerites of Southwestern Iowa: A Latter-day Saint Schism and its Role in the Early Settlement of Iowa
}

\author{
DANNY L. JORGENSEN
}

ALPHEUS CUTLER (1784-1864) and about one hundred devoted followers formally organized the schismatic Church of Jesus Christ (Cutlerite) in southwestern Iowa on September 19, 1853. These people, known popularly as "Cutlerites" after their primary leader, were Latter-day Saint (LDS or Mormon) dissenters. ${ }^{1}$ Shortly after the martyrdom of Joseph Smith Jr., the founding LDS prophet, in 1844, the future Cutlerites initially accepted Brigham Young's leadership of the largest remnant of the Nauvoo, Illinois, church. They also were a part of the mass

I appreciate the many forms of assistance provided by the Shenandoah Historical Society, especially Jackie Simpson and the late Lucielle Hoppoch. I am also indebted to Biloine Whiting Young for continued support; and I gratefully acknowledge the assistance of Tina Neville of the Nelson Poynter Memorial Library, the University of South Florida, St. Petersburg; the Library-Archives of the Reorganized Church of Jesus Christ of Latter Day Saints, Independence, Missouri; and the Archives of the Church of Jesus Christ of Latter-day Saints, Salt Lake City, Utah.

1. Chancey Whiting, Manti Book Number One, unpublished manuscript, 1853, Library-Archives, Church of Jesus Christ of Jesus Christ of Latter Day Saints, Independence, MO; Rupert J. Fletcher and Daisy Whiting Fletcher, Alpheus Cutler and the Church of Jesus Christ (Independence, MO, 1974); Danny L. Jorgensen, "The Old Fox: Alpheus Cutler," in Roger D. Launius and Linda Thatcher, eds., Differing Visions: Dissenters in Mormon History (Champaign, IL, 1994), 312-58; Danny L. Jorgensen, "Conflict in the Camps of Israel: The Emergence of the 1853 Cutlerite Schism," Journal of Mormon History 21 (1995), 24-62. Although some records indicate that Cutler's first name was John, there is no record that anyone called him anything but Alpheus.

THE ANNALS OF IOWA 58 (Spring 1999). (CThe State Historical Society of Iowa, 1999. 
exodus from the Latter-day Saints' "Kingdom on the Mississippi" beginning in early $1846 .^{2}$ Joining what the westward bound Saints called the Camps of Israel, the future Cutlerites trekked across Iowa from 1846 to about 1851.

Cutler and his later followers, as participants in the Camps of Israel, helped establish Mormon way stations and encampments at Garden Grove, Mount Pisgah, and other southern Iowa locations. ${ }^{3}$ They buried their dead along the Iowa trails and into Indian Territory across the Missouri River at the Saints' Winter Quarters (present-day Florence, Nebraska). While still a part of Brigham Young's organization, they founded encampments at Silver Creek and Farm Creek in present-day Mills County, Iowa. ${ }^{4}$ Following conflict with LDS authorities at the Missouri and immediately before the formation of the Cutlerite church, they established another frontier village, named Manti after a location in their Book of Mormon scripture. ${ }^{5}$ The present-day town of Shenandoah developed from this once thriving farming village. In 1857 the Cutlerites also inaugurated a short-lived colony and gristmill, called Mormontown by the local nonMormon inhabitants, on the Platte River in Taylor County, Iowa. That Cutlerite settlement resulted in the development of the present-day village of Blockton. ${ }^{6}$

2. Robert Bruce Flanders, Nauvoo: Kingdom on the Mississippi (Urbana, IL, 1965). For a sound historical overview of the Latter-day Saint religion, see Leonard J. Arrington and Davis Bitton, The Mormon Experience (Urbana, IL, 1992).

3. Leland H. Gentry, "The Mormon Way Stations: Garden Grove and Mount Pisgah," Brigham Young University Studies 21 (1981), 445-61; Karla Gunzenhauser, "The Settlement at Garden Grove, Iowa," Nauvoo Journal 6 (1994), 15-22; Stanley B. Kimball, "The Mormon Trail Network in Iowa, 1838-68," Brigham Young University Studies 21 (1981), 417-30; idem, Historic Sites and Markers along the Mormon and Other Great Western Trails (Urbana, IL, 1988); idem, Historic Resource Study: Mormon Pioneer National Historic Trail (Washington, DC, 1991).

4. Danny L. Jorgensen, "Cutler's Camp at the Big Grove on Silver Creek: A Mormon Settlement in Iowa, 1847-1853," Nauvoo Journal 9 (1997), 25-42.

5. Gary Latimer, The Manti Story (Shenandoah, IA, n.d.), 1, speculates reasonably that "the heart of the Manti settlement was made among this area's hills, thus the name Manti, or hill." See also Joseph Smith Jr., trans., The Book of Mormon (rev. ed., Salt Lake City, 1981), especially Alma 1:15; 57:22; 58:1, 13, 2528 , and 39, where Manti is identified as a person, region, province, hill, and city.

6. Vivian Johnson, ed., Centennial History of Mormontown, Iowa (Bedford, IA, 1961). 
The Mormon trek across Iowa is a significant part of the Latter-day Saints' westward migration and sacred story. ${ }^{7} \mathrm{Al}-$ though most of the Saints had continued west by the early 1850s, they contributed to the development of the southern portion of Iowa. Immediately before and after Iowa attained statehood in December 1846, the Mormons blazed trails, built roads, bridges, and ferries, and established settlements. Much less is known about the Mormons who remained in Iowa and contributed to its further development. The founding of Manti and the other community-building activities of the Cutlerites are familiar to some current residents of the area, but scholars have largely neglected the history of this schismatic LDS group in southwestern Iowa. ${ }^{8}$ This essay corrects that oversight by describing the Cutlerites' role in the founding of four Iowa settlements, two of which became permanent communities.

7. The Mormon Trek across Iowa has stimulated considerable interest and scholarly research. See, for example, Charles H. Babbitt, Early Days at Council Bluffs (Washington, DC, 1916); Maureen U. Beecher, ed., "The Iowa Journal of Lorenzo Snow," Brigham Young University Studies 24 (1984), 261-74; Ruth S. Beitz, "Where the Saints Have Trod," Iowan 10 (Winter, 1962), 18-23; Richard Bennett, Mormons at the Missouri, 1846-1852: "And Should We Die . .." (Norman, OK, 1987); Lawrence Coates, "Refugees Meet: The Mormons and Indians in Iowa," Brigham Young University Studies 21 (1981), 491-514; Susan W. Easton, "Suffering and Death on the Plains of Iowa," Brigham Young University Studies 21 (1981), 431-39; Lida L. Green, "Markers for Remembrance: The Mormon Trail," Annals of Iowa 40 (1970), 190-93; R. E. Harvey, "The Mormon Trek across Iowa Territory," Annals of Iowa 10 (1946), 36-60; Gail G. Holmes, "The LDS Legacy in Southwestern Iowa," Ensign (1988), 54-57; William J. Petersen, "Mormon Trails in Iowa," Palimpsest 47 (1966), 353-84; William G. Hartley, My Best for the Kingdom: History and Autobiography of John Lowe Butler, A Mormon Frontiersman (Salt Lake City, 1993); and Susan Easton Black and William G. Hartley, eds., The Iowa Mormon Trail: Legacy of Faith and Courage (Orem, UT, 1997).

8. See, for example, S. A. Burgess, "The Latter Day Saints in Iowa," Journal of History 17 (1924), 129-48; R. E. Cunningham, ed., Manti: The Grove, the Town, the Cemetery (Shenandoah, IA, n.d.); idem, ed., Southwest Iowa's Heritage: A History of Page and Fremont Counties (Shenandoah, IA, 1973); Nick Lamberto, "Old Iowa Ghost Town Becomes a Park," Des Moines Sunday Register, 9 December 1962 (Picture Magazine Section); Gary Latimer, "Shenandoah Centennial, 1871-1971," unpublished MS, 1971, Shenandoah.Historical Museum, Shenandoah, IA; Charles Fry, "History of Fremont (Iowa) District, Early Settlers, 1846," Journal of History 2 (1909), 345-59; History of Fremont County, Iowa (Des Moines, 1881); and L. H. Van Gilder et al., eds., Anecdotes of the Midwest (Plainfield, NJ, n.d.). 


\section{APPROXIMATELY FOUR TO FIVE HUNDRED PEOPLE} eventually became Cutlerites (or were affiliated closely with them in Iowa). They were predominantly literate New England farmers and tradesmen of middling economic status. ${ }^{9}$ Most of them had converted to Mormonism during the early to middle 1830s, after the new religion founded by Joseph Smith Jr. in 1830 in New York had moved to Ohio. They were typical of the people who followed Smith from Ohio to Missouri in the 1830s and, after their expulsion from Missouri in 1838-1839, to Illinois. The future Cutlerites participated fully in the LDS church between 1839 and 1846. Most of the men had been ordained to the lay priesthood, and many of them had performed significant leadership roles. Some of them had been instructed in the radically innovative LDS temple theology, and many of them had received temple endowments at Nauvoo. A few of them also had been initiated into the most sacred LDS rites, including celestial (plural) marriage and family relations. ${ }^{10}$

Following Joseph Smith's martyrdom in 1844, the Nauvoo church was in organizational disarray. Some members were in open dissent, various factions and rival organizations had emerged, and members were scattered across the eastern and midwestern states. Even the core membership from Nauvoo was moving and scattered from the Mississippi River to the Rocky Mountains. It is therefore impossible to specify on a case by case basis who was and was not a "member" of any particular faction or organization or precisely what that meant to those people and their contemporaries. Through the late 1840 s and early 1850 s, those people who were to become Cutlerites remained with the largest body of Latter-day Saints rather than becoming dissenters or joining any of the existing or emergent splinter groups. ${ }^{11}$ The

9. Danny L. Jorgensen, "The Social Backgrounds and Characteristics of Those People Who Founded the Church of Jesus Christ (Cutlerite)," paper presented to the Mormon History Association, Quincy, IL, 1989. The earliest Cutlerite membership records (from 1853) list the names of about one hundred baptized members. Other evidence, however, clearly indicates that as many as five hundred people, almost all whom had been members of the Nauvoo Mormon church, were affiliated with the Cutlerite church in Iowa during this period.

10. Jorgensen, "Conflict in the Camps of Israel," 28-34.

11. D. Michael Quinn, "The Mormon Succession Crisis of 1844," Brigham Young University Studies 16 (1976), 187-234. 
group was bound by friendship, kinship, and a shared experience of living in the same communities, but they did not yet compose a distinctive Mormon faction. "Father" Cutler, as he was known respectfully, contributed to the work of the LDS Council of Twelve Apostles, which, under the direction of Brigham Young, assumed temporary leadership of the larger, fragmented movement, although only nine of the twelve remained together.

At Nauvoo, Alpheus Cutler had held the rank of High Priest (the highest regular office in the lay priesthood), and he had been part of Joseph Smith's elite leadership circle. ${ }^{12} \mathrm{He}$ had been a member of the Nauvoo High Council (the highest local governing body of the church), a policeman and one of the prophet's bodyguards, and a primary supervisor for construction of the temple, the ultimate religious symbol of the Saints' effort to restore the Kingdom of God on earth. Cutler had been one of the first Saints Smith had selected for membership on the secretive, parapolitical Council of Fifty. ${ }^{13}$ Cutler, like most of the Fifty, believed that the prophet had charged that body with exclusive authority and responsibility for building the theocratic Kingdom of God on earth-whereby the Saints aimed to politically transform the United States government and, ultimately, all earthly governments. Even more significantly, Cutler had been a member of the Mormon prophet's highly selective, covert, Anointed Quorum. Joseph Smith had instructed Cutler-and the entire Anointed Quorum-in the newest and most sacred doctrines of Nauvoo Mormonism. Cutler and the other members of the Anointed Quorum also were the first Saints Smith initiated into the temple salvation rites, especially the still secret practice of celestial (plural) marriage and kinship relationships. ${ }^{14}$

12. Fletcher and Fletcher, Alpheus Cutler, 9-63; Jorgensen, "The Old Fox."

13. D. Michael Quinn, "The Council of Fifty and Its Members, 1844 to 1945," Brigham Young University Studies 20 (1980), 163-96; idem, The Mormon Hierarchy: Origins of Power (Salt Lake City, 1994), esp. chaps. 4-7; Andrew F. Ehat, "'It Seems Like Heaven Began on Earth': Joseph Smith and the Constitution of the Kingdom of God," Brigham Young University Studies 20 (1980), 253-79.

14. D. Michael Quinn, "Latter-day Saint Prayer Circles," Brigham Young University Studies 18 (1978), 79-105; idem, The Mormon Hierarchy, 113-17; Andrew F. Ehat, "Joseph Smith's Introduction of Temple Ordinances and the 1844 Mormon Succession Question" (M.A. thesis, Brigham Young University, 1981). 
Cutler, like other members of the Council of Fifty, helped organize the Saints' exodus from Illinois, which commenced in February 1846. He led an advance party of the Camps of Israel across Iowa and founded the first European-American town west of the Missouri River in Indian Territory (now Nebraska). ${ }^{15}$ Located just north of what would become Omaha, it was named Cutler's Park by Brigham Young. ${ }^{16}$ Cutler subsequently helped select the site of the Saints' Winter Quarters on the Missouri, where he assumed the presidency of the LDS High Council (the local government). In the spring of 1847 the Apostles sent an advance expedition to the Rocky Mountains. After establishing a pioneer settlement in the Valley of the Great Salt Lake, many of the ranking LDS leaders returned to the Missouri camps.

In 1847 Cutler encountered some familiar New York Indians at Winter Quarters. Apparently Cutler and some of these Indians had known one another previously in the East, perhaps dating as far back as the War of 1812. The encounter reminded Cutler of a previous Council of Fifty commission from Joseph Smith to minister to the "Lamanites" (the name given to American Indians in the Book of Mormon). ${ }^{17}$ With the blessing of Brigham Young and the LDS Apostles, Cutler and James W. Cummings, another member of the Council of Fifty, journeyed south in December. Near their destination, they joined Lewis Denna, an Oneida Indian and Mormon elder. A member of the Council of Fifty, Denna was the highest ranking Native American in the Nauvoo Mormon church. ${ }^{18}$ Cutler and Denna formu-

15. Jorgensen, "Conflict in the Camps of Israel," 34-38. At that time everything the United States owned west of the Missouri was designated as Indian Territory and, therefore, remained closed to Euro-American settlement. Furthermore, the Far West would remain a part of Mexico for the next few months.

16. A memorial marks the site about two-and-a-half miles northwest of the LDS Winter Quarters cemetery in north Omaha.

17. Danny L. Jorgensen, "Building the Kingdom of God: Alpheus Cutler and the Second Mormon Mission to the Indians, 1847-1853," Kansas History 15 (1992), 192-209.

18. James Willard Cummings Papers, 1839-1852, Archives, Church of Jesus Christ of Latter-day Saints, Salt Lake City (hereafter cited as LDS Church Archives). LDS sources commonly use the spelling Dana, rather than the Cutlerite spelling Denna. I take the Cutlerite spelling as authoritative because it is the spelling his wife had inscribed on his grave marker in the Cutlerite cemetery at Clitherall, Minnesota. 
lated a plan to secure a homeland for the New York Indians on the Delaware Reservation southwest of Fort Leavenworth in Indian Territory, near the confluence of the Grasshopper (Delaware) and Kaw (Kansas) Rivers. The plan included permission for a Mormon mission on the reservation and contracts with federal agents. Elder Denna stayed to work out the details, while Cutler and Cummings returned to Winter Quarters. ${ }^{19}$

Over the next few days, Cutler participated in a series of meetings with ranking Mormon authorities. He enthused about the possibilities of a mission and suggested to Brigham Young that the Mormons form an alliance with the Indians. A large organized armed force, he argued, would prevent interference from their enemies, and it might be used to vindicate longstanding grievances with the Missourians, perhaps including taking Fort Leavenworth by force! Young and the Council, knowing that armed resistance might become necessary, approved Cutler's Indian ministries but cautioned that such an alliance also might provoke rather than prevent violence. ${ }^{20}$

At the same time, the Mormon Apostles had other critical business. That December they reorganized the LDS hierarchy, with Brigham Young as president and Willard Richards and Heber C. Kimball as counselors. Federal permission for the Saints' encampments on Indian lands had expired, so the Apostles directed the Saints at the Missouri to continue west or return to Iowa to make further preparations. In the spring of 1848, the Saints abandoned the camps along the west bank of the Missouri River, and Young returned to the Utah outpost. Orson Hyde, the newly designated president of the Apostles and of a reconstituted High Council at Kanesville (Council Bluffs), was assigned administrative authority for the Saints who remained in Iowa and the East.

RETURNING TO IOWA, Cutler joined kinfolk and friends at an LDS encampment on Silver Creek. That site, commonly described as "Cutler's Camp at the Big Grove on Silver Creek,"

19. Richard E. Bennett, "Lamanism, Lymanism, and Cornfields," Journal of Mormon History 13 (1986-87), 45-59; idem, Mormons at the Missouri, 69.

20. Ibid. 
was typical of the numerous settlements established by the westward-bound Saints along the Missouri River. Migrating Mormons had begun gathering at this location, about halfway between the present towns of Malvern and Silver City, in $1847 .^{21}$ At that time, there were very few settlers, established communities, or geographic-political divisions in the area. Cutler's camp was located in what eventually became Silver Creek Township in Mills County after that county separated from Pottawattamie County. The Mormon trails linked the camp to way stations and settlements east across southern Iowa and west to Kanesville, the hub of LDS activities, and the ferries across the Missouri River.

The creek at Cutler's camp may have been named after the Cutlers' former home town in New York. A grove on the hillside overlooking the creek no doubt supplied the Saints with food, fuel, and building materials, while the stream provided for transportation and commerce. The Silver Creek Saints constructed several gristmills on the creek. Cordelia Morley Cox, one of the Mormon residents, reported that the first mill was built (probably in 1847) by "hollowing a [tree] stump [and] arranging a spring pole, so that in a kind of mortar and pestle fashion [they] could pound enough coarse meal to do the family all day." She also observed that the Saints "usually had pancakes for breakfast, cornbread for dinner, with plenty of milk, butter and eggs." ${ }^{22}$

21. D. C. Bloomer, "Notes on the History of Pottawattamie County," Annals of Iowa 9 (1871), 522-33, 666-81; Clare B. Christensen, Before and After Mt. Pisgah: Cox, Hulet, Losee, Morley, Tuttle, Winget, Whiting and Related Families (Salt Lake City, 1979), 175-86; Mills County History Book Committee, Mills County, Iowa (Dallas, 1985), 514; Allen Wortman, Ghost Towns of Mills County Iowa (Malvern, IA, 1975), 26; Fry, "History of Fremont (Iowa) District," 346-47. The Silver Creek settlers' oral tradition credited the Cox and Whiting families with founding the encampment, but also noted that the Bakers, Cutlers, Fishers, Follets, Davises, Shermans, Murdocks, Pattens, and others located there or nearby. See Christensen, Mt. Pisgah, esp. 129-66 and 175-216.

22. Quoted in Christensen, $M t$. Pisgah, 182. Other mills subsequently located along Silver Creek. A second mill was probably constructed in 1849 or 1850. Wortman, Ghost Towns, 26. In 1856, according to Mills County, 92, Aaron Lewis dammed Silver Creek and constructed the "Rock Ford Mill." George Patrick subsequently updated and renamed it, using it until it was torn down in 1912. 
In the somewhat protected area between the creek and the hillside, an area of about twenty acres, the Silver Creek Saints resided in wagons and tents. They also built a few small, primitive $\log$ dwellings. ${ }^{23}$ Though not very expansive, the site was sufficient for gardening. The settlers raised potatoes, squash, sweet corn, and other vegetables, sometimes in enough quantity to trade for other provisions. When they attempted more extensive farming, they had to locate their fields beyond the grove on the prairie. The Silver Creek settlers reported that it took considerable effort to plow the virgin prairie sod. Once turned, the farmer would "strike each sod with an ax, and into the hole so made" a helper would drop corn seed. The surrounding grasslands provided ample grazing as well as hay. The Saints' livestock included horses, oxen, cattle, chickens, and possibly hogs and sheep. The settlers also established a cemetery east of the grove about halfway up the incline on the side of the next hill. ${ }^{24}$

This encampment on Silver Creek, like most of the many Latter-day Saint settlements surrounding Kanesville in southwestern Iowa, was established as a temporary stopping place on the westward trek. While some of the Saints remained at the camp for a few days or a few weeks before resuming the trip west, others resided there for months, sometimes even years. F. Walter Cox and his plural families, for example, resided at Silver Creek for nearly two years before moving on to Utah. There is no record of exactly how many people moved through

23. According to the settlers' oral tradition, a typical cabin was "not more than fourteen feet square." It was "shingled with split timber about three feet long" and included "one four light window." The furnishings typically included handmade chairs, tables, and bunk beds with "split timber for slats upon which they put ... straw mattresses." This small space sometimes was divided in half by extending "a pole across the room with a crotched stick." When they could afford it, settlers used a wood-burning stove to heat the structure. Christensen, Mt. Pisgah, 184.

24. Christensen, Mt. Pisgah, 182, 179. The cemetery included about a dozen graves, although there is no sign of them today. A county history notes that several settlers died the first winter and were buried about $1 / 4$-mile south and $1 / 4$-mile west of the present cemetery. Some of the unmarked graves, thought to be Mormon, are located "in the north central area of the cemetery," while others were discovered "northwest to southeast ... just over the fence directly south of the main door of the [East Liberty Methodist] church." Mills County, 5, 92-93. 
or lived at Cutler's Camp on Silver Creek. The bits and pieces of available information suggest that no more than about twenty families resided there at any one time. However, the total number of Mormons who stopped at the site between 1847 and about 1853 probably was considerably larger. ${ }^{25}$

When Cutler returned to Iowa in 1848, he assumed the presidency of an existing LDS branch (congregation) at Silver Creek. Cutler and some of his followers were eager to pursue Indian ministries. On the Delaware reservation in Kansas, they already had established a mission consisting of a few cabins, gardens, farms, and a gristmill. ${ }^{26} \mathrm{~A}$ few families resided at the Kansas mission permanently or for extended periods of time, while Cutler and some of the LDS missionaries moved back and forth between their Silver Creek headquarters and the mission. Beginning in the fall of 1848, however, rumors about Cutler's Lamanite activities and related, possibly heretical teachings disturbed the Kanesville High Council. Their investigation provoked a long, bitter, and complicated dispute with Cutler and especially some of his more zealous followers at Silver Creek. ${ }^{27}$

APOSTLE ORSON HYDE and the Iowa High Council found the task of moving the Saints west laden with problems. The Cutlerites, as Hyde and others had started calling Cutler and his followers, increasingly came to symbolize many of those difficulties. ${ }^{28}$ Thousands of Mormons remained scattered across Iowa and along the Missouri in wagon clusters, temporary encampments, and way stations. They were weary, impoverished, dis-

25. Christensen, Mt. Pisgah, 182-86, 213-14.

26. Wortman, Ghost Towns, 26; Art Johnson, "Three Find Long-Lost Mormon Camp," Omaha World-Herald clipping, n.d.; Jorgensen, "Cutler's Camp at the Big Grove on Silver Creek; idem, "Building the Kingdom of God," 206-7; A. T. Andreas, History of the State of Kansas (Chicago, 1883), 499-500; Elmer L. Brown, "Early History of Thompsonville," unpublished MS, 1966, in author's possession.

27. Jorgensen, "Conflict in the Camps of Israel." See also Orson Hyde, George A. Smith, and Ezra T. Benson (representing the Kanesville High Council), "Report to Brigham Young and Council of Twelve," 15 March to 5 April 1849, LDS Church Archives.

28. Bennett, Mormons at the Missouri, 69. 
eased, and dying. The innovative temple theology and related practices, especially plural marriage, remained secretive, controversial, and uninstitutionalized. The organizational structure of the movement was confusing and ambiguous, in spite of Young's reorganization in 1847. Hyde and the Council perceived that widespread heresy, apostasy, rival claims to leadership, and organizational fragmentation threatened the security and even existence of this fragile movement. They came to regard some of the teachings and claims of Cutler's more zealous Silver Creek followers as heretical. Hyde and the Council tried to command the Cutlerites' obedience, but they failed. They were also unable to coerce the Cutlerites into moving west immediately. Consequently, the High Council, sustained by an LDS church conference in Iowa, disfellowshipped some of the Cutlerites and suspended Cutler's Indian mission until further notice. ${ }^{29}$

Cutler's plans for the Indian mission mostly went unrealized. Only a few bands of New York Indians relocated to the Delaware reservation. The LDS missionaries made no lasting converts; they had trouble with the mill, and problems with federal agents; they were unable to secure title to farms and other improvements on Indian lands; and they suffered from extreme poverty. By 1851, hardships and disease had taken the lives of several women and children, including Henrietta Clarinda Miller, Cutler's youngest plural wife and her newborn child, as well as two of Cutler's daughters, Clarissa and Emily, both of whom had been plural wives of LDS Apostle Heber C. Kimball (who by now was a member of the ruling First Presidency in Utah) until their monogamous remarriages within the previous three years. The Delawares also suffered considerably from poverty and disease, and they and their agents had conflicts with the missionaries. Thus, after a few months, most of the Indians who had migrated became discouraged and returned east. ${ }^{30}$

29. Orson Hyde, ed., "Minutes of the Conference of the Church of Jesus Christ of Latter-day Saints held at Kanesville, Pottawattamie County, Iowa," Frontier Guardian (Kanesville, Iowa), 30 October 1850.

30. Stanley B. Kimball, Heber C. Kimball: Mormon Patriarch and Pioneer (Urbana, IL, 1986), 243-44, 308; idem, ed., On the Potter's Wheel: The Diaries of Heber C. Kimball (Salt Lake City, 1987), 133; Abraham Kimball, Finding a Father: Gems for the Young Folks (Salt Lake City, 1881); A. Kimball, "Reminiscences and Journal, 1877-1889," LDS Church Archives. 
Cutler, in pursuit of the Indian mission, had ignored the High Council's demand to appear before them and account for his activities. Convinced that he had no intention of moving west, the Council excommunicated him in April 1851. Cutler had appealed his previous disfellowship directly to Brigham Young in Utah. President Young's several communications were warm, affectionate, and clearly acknowledged exceptionally powerful, intimate bonds between these old friends. He reassured Cutler that his continued participation in Utah Mormonism was valued highly. Brother Brigham counseled Cutler to bring his family and followers west as soon as possible, but he did not revoke the High Council's sanctions. ${ }^{31}$

After that time, further westward progress and continued participation in Utah Mormonism would have been difficult at best for the Cutlerites. Cutler, like many of the Indian missionaries and other followers, was impoverished and in poor health. The Cutlerites were weary from twenty years of pioneering and religious persecution. Cutler had become increasingly committed to and responsible for a zealous core of followers. The emergent Cutlerites were fully devoted to a mostly orthodox Nauvoo Mormonism, but through prolonged conflict with the Iowa High Council some of them had formulated somewhat distinctive claims and doctrines. ${ }^{32}$ Although Cutler had a plural marriage, few of his followers did. Yet most of them were intimately familiar with its practice by close friends and other family members, and increasingly some of them found it revolting. Many of the Cutlerites, moreover, had experienced the directives of the Iowa High Council as tyrannical. They had become disdainful of the Council's legitimacy and of the larger "Brighamite" movement, as they called it. Some of them, consequently, began

31. Cutler to Young, 23 April 1848 and 13 June 1850; Young to Cutler, 21 April 1848, 21 October 1849, and 14 September 1852, all in LDS Church Archives.

32. Danny L. Jorgensen, "The Fiery Darts of the Adversary: An Interpretation of Early Cutlerism," John Whitmer Historical Association Journal 10 (1990), 67-83.

33. According to Fletcher and Fletcher, Alpheus Cutler, 44-45, "The first task [of the newly organized Cutlerites] was to eradicate any taint of plural marriage. Few families had escaped the embarrassment and humility [sic] of having daughters espoused as plural wives to leading men of the church, or suffered the shame of seeing sons, brothers, or fathers participate in the practice." 
seriously entertaining the possibility of locating permanently in Iowa and forming an independent religious organization.

\section{CUTLER AND HIS FOLLOWERS abandoned the Kansas} Indian mission sometime in late 1851 or early 1852 . Shortly after the missionaries returned to Iowa, the Silver Creek settlers packed up and moved. ${ }^{34}$ Several factors probably contributed to their decision: the creek may have been too small, too unpredictable, or otherwise unsuitable as a mill site; the hilly, surrounding countryside presented greater difficulties for farming than they could solve with their technology; and family, friends, and other Saints remained scattered near more desirable locations in southwestern Iowa. In addition, a familiar pattern of conflict with the local government had begun to emerge; in 1851 Iowa authorities arrested Cutler and at least one other Mormon, F. Walter Cox, at Silver Creek for practicing plural marriage. Cox complied by temporarily moving two of his three wives to other jurisdictions and leaving for Utah in 1852. Cutler "put aside" his remaining plural wives. Exactly what that meant is not clear. At least one of them, Luana Hart Beebe Rockwell, and her children-including two, Jacob and Olive, by Cutler-continued to reside among the Cutlerites. ${ }^{35}$

Sometime after the Cutlerites' departure from Silver Creek, their cabins were moved to other locations and used as temporary shelters by later farmers. Reportedly, "quite a community

34. Fletcher and Fletcher, Alpheus Cutler, 46-48.

35. Christensen, Mt. Pisgah, 183-84. Whether or not Luana and Alpheus continued to sustain some kind of marital relationship is unknown. Luana remarried at least twice (to Wheeler Baldwin and Isaac Perry), but there is no record of any children from those unions, and it is entirely possible that they were intended to provide for her welfare or to disguise her past and perhaps ongoing relationship with Cutler. There is almost no record of what happened to Cutler's other plural wives. It seems likely that the "old shepherdess" known as "Laura Lang" and "Aunt Laurie" who resided later among the Minnesota Cutlerites at Clitherall for many years had been one of those wives, but there is no conclusive evidence for this strong suspicion. The founding Cutlerites earnestly endeavored to distance themselves from the practice of plural marriage, and they mostly were successful in hiding Cutler's plural marriages and wives from their children and later generations. The Cutlerites who are alive today sincerely believe that Alpheus never participated in plural marriage, and they greatly resent any claim to the contrary. 
arose around the mill." The same report also noted that "George Patrick, Lee Adams, and some others living up the Silver Creek were talking of laying out a new town in the vicinity of the Patrick Mill and 'making a pull for the county seat."' Some of the Cutlerite cabins were dragged halfway up an adjoining hillside northeast of the Big Grove, where a settlement called Wall Street existed until after the turn of the century. ${ }^{36}$

Beginning in 1852 Cutler's followers from Silver Creek and other Iowa locations started gathering at a site about twentyfive miles southeast of the Big Grove encampment. Located in present-day Fremont County (on the boundary with Page County), the new settlement had been founded around 1847 or 1848 by Edmund Fisher, a former Mormon and Cutlerite recruit. ${ }^{37}$ The area was mostly rolling prairie, but the settlement site was marked by a hickory grove of approximately thirty acres covering a hillside above a small stream. The creek, grove, and township retained Fisher's name, as originally designated, while the Cutlerites renamed the little frontier settlement Manti, after a prominent location in the Book of Mormon. Eventually, about forty Mormon families associated with Cutler relocated there. Other LDS families associated with or belonging to the Cutlerite church-a total of four or five hundred people-were still scattered over the southwestern corner of Iowa.

IN 1853 the Cutlerites finally decided to form a religious organization independent of the Utah church, largely because of their previous conflict with Apostle Orson Hyde and the Iowa High Council. In spite of the Council's charges of heresy, the Cutlerite schism did not originate in substantial doctrinal differences. The initial conflict was mostly about the timing and appropriateness of Cutler's Indian mission compounded by a dispute about whether Cutler or the Council had ultimate authority over this Lamanite mission. The disfellowship and excommunication of Cutler and some of his followers hardened

\section{Mills County, 5, 92.}

37. Fletcher and Fletcher, Alpheus Cutler, 55-56; History of Fremont County, 542-43. These sources agree that Fisher founded the first American settlement there, but they do not agree on the exact date. Fisher was there in 1849 when D. S. Brown arrived, long before 1852, when the Silver Creek Saints began to gather there. 
the lines of conflict over objectives and authority. The Council's actions were intended to persuade or coerce Cutler and his followers into moving west, but the sanctions had the opposite effect because the Cutlerites perceived them as tyrannical.

All of the Cutlerites' beliefs were grounded in Nauvoo Mormonism, and none of them were inherently heretical. In fact, many other Latter-day Saints (including some in Utah) shared many of the Cutlerites' beliefs and claims. Once the Council's sanctions had been imposed and Cutler's appeals to Brigham Young had failed, however, the Cutlerites were left with few choices. From their perspective, any reconciliation with the Utah church would mean admitting that they were at fault. That alternative was unacceptable to most of them. Instead, some of Cutler's followers decided to form an independent organization, an action they viewed as an effort to preserve the true principles of Nauvoo Mormonism. That decision, in turn, provoked the Cutlerites to institutionalize their understanding of the Saints' Nauvoo experience as distinct from the doctrinal and institutional developments that were under way within the LDS Church in Utah. ${ }^{38}$

Alpheus Cutler and his followers formally organized the independent Church of Jesus Christ (Cutlerite) at Manti on September 19, 1853. Cutler's claims to priestly authority for the Latter-day Saint restoration of Christianity, the Cutlerites affirmed, derived from the private doctrines that he had learned from Joseph Smith. Those beliefs included a common Latterday Saint contention that God had recently rejected the earthly church because of the Nauvoo Saints' transgressions (failure to live the commandments of God). That rejection, they asserted, was signified by Smith's murder in 1844 and sealed with his blood. Adding a unique twist to this otherwise common LDS belief, the Cutlerites maintained that God had thereby also rejected further efforts to convert the Gentiles (non-Mormons) because they had murdered the prophet. (Jews and Lamanites [Indians] were still prospects for conversion because they were not implicated in the prophet's murder.)

38. Fletcher and Fletcher, Alpheus Cutler, 36-55; Jorgensen, "The Fiery Darts of the Adversary," 71-77. 
To buttress Cutler's claim to authority, his followers argued in typical Mormon legalese that God had promised that the path to eternal salvation would never again be blocked. Thus God had provided for the continuation of the Priesthood and Celestial Kingdom. Joseph Smith had ordained Alpheus Cutler -along with the rest of his entire Anointed Quorum-at Nauvoo with the Keys to the Priesthood and the Kingdom to reign as Priest and King in Zion. ${ }^{39}$ Cutler's claim to authority was reinforced further by his membership in the Nauvoo Mormon Council of Fifty. The Cutlerites subsequently maintained that since the six higher-ranking members of Smith's special leadership quorum were dead or in apostasy, authority for the Priesthood and Kingdom fell exclusively to Cutler, who knew what needed to be done to salvage the Latter-day Saint restoration of Christ's true church. In this way the Cutlerites blended the otherwise ordinary claims of Joseph Smith's Anointed Quorum and the Council of Fifty. After Cutler received a heavenly sign ("two half moons with their backs together") fulfilling a prophecy attributed to Joseph Smith, the Cutlerites argued that he had little choice but to reorganize the earthly church of Jesus Christ. ${ }^{40}$ Although some of his followers also claimed that Cutler was Joseph Smith's prophetic successor, Cutler himself consistently limited his claims to authority for the Priesthood and the Kingdom. ${ }^{41}$

The Manti Cutlerites, like the early Latter-day Saints, fundamentally aimed to practice a restored, primitive Christianity and build the utopian Kingdom of God on earth (Zion) in preparation for the Second Coming of Jesus Christ and the Millennium. Their reorganization acknowledged Joseph Smith as God's prophet; their basic platform of faith included the standard LDS scriptures - the (King James) Bible, Book of Mormon, and Doctrine and Covenants - along with the Constitution of the United States of America. Cutler stood at the head of this reorganization as the President of the Priesthood, with authority over the Kingdom, supported by first and second counselors

39. Quinn, Origins of Power, 105-42, 203-9. See also David John Buerger, The Mysteries of Godliness: A History of Mormon Temple Worship (San Francisco, 1994), esp. 35-68.

40. Fletcher and Fletcher, Alpheus Cutler, 47.

41. Frederick B. Blair, ed., Memoirs of President W. W. Blair (Lamoni, IA, 1909). 
representing a First Presidency. This Kingdom was the biblical theocracy envisioned by the Puritans as the Kingdom on the Hill and later appropriated by Joseph Smith. It was to be the highest government on earth, supplanting all earthly governments. To maintain the distinction between the church and the Kingdom, the Cutlerites also elected a president of the church. The president, along with two counselors he selected, presided over all meetings of the church, but not the Kingdom. The Cutlerites retained the standard Latter-day Saint lay ministry: an Aaronic priesthood consisting of deacons, teachers, and priests; and a Melchizedek priesthood of elders and high priests. For unknown reasons, however, they did not institute the customary LDS Council of Twelve Apostles or the quorums of Seventies. Previously, in 1849, Cutler had ordained Pliny Fisher to the special priesthood office of Patriarch. ${ }^{42}$

Like the Utah Mormons, but unlike most other early Latterday Saint factions, the Cutlerites retained the Nauvoo temple salvation theology and rituals, with the significant exception of celestial (plural) marriage. At Manti they enacted the "endowment," complete with the issue and use of sacred undergarments, as well as the other temple rituals (such as baptism for the dead and the fullness of the priesthood) that Cutler had learned from Joseph Smith at Nauvoo. The Cutlerites never constructed a temple; however, they sanctified the second story of all of their subsequent meetinghouses for the performance of temple rituals, so that is probably where the rituals were conducted at Manti.

The Cutlerites reinforced their belief in the Nauvoo salvation theology with the practice of a full range of the charismatic gifts of the spirit, including prophecy, miracles, visions, speaking in and interpreting tongues, and the laying on of hands (especially for healing). Cutlerism, like other versions of the early Latter-day Saint religion, also aimed to enact the "more perfect" Order of Enoch (owning all material things in common) rather than the "less perfect" economic principle of tithing. Participation in this form of economic communalism was voluntary. Some of the Manti Cutlerites had little to dedicate to the Order,

42. Pliny Fisher, "Book of Patriarchal Blessings," 1859, RLDS Library-Archives, Independence, $\mathrm{MO}$. 
and others did not participate fully, so they were never entirely successful at sustaining a united economic order.

The Cutlerites generally envisioned their existence at Manti as a quasi-democratic theocracy modeled after the Nauvoo Mormon Kingdom of God. For these mostly self-sufficient Iowa pioneers, the church served as both religion and government. They took the LDS scriptures as the law. The Cutlerite High Council (eventually defined as the High Priests' Quorum) operated as a theocratic executive and judiciary, interpreting and administering the law as well as conducting trials and punishment as necessary. ${ }^{43}$ The Manti Cutlerites therefore did not organize an ordinary secular government, although some Cutlerites and people closely related to them did participate, as individuals, in local politics and government. Milton Richards, a former Mormon and the son of Farm Creek Cutlerite Augustus Richards, named and platted Sidney, the seat of Fremont County beginning in $18511^{44}$ The Cutlerites also submitted to the established secular governments. During the "War of the Rebellion," as they called the Civil War, the men complied with civil laws by enlisting in the Iowa Border Guard. ${ }^{45}$

AT MANTI the Cutlerites proceeded to build a permanent settlement. First they constructed single-family log dwellings forming the village of Manti, and they erected additional log cabins and outbuildings on the surrounding farmlands. The settlers established gardens, farms, cottage industries, and businesses. Farming was the economic backbone of the Cutlerite community. Most families raised a garden and other crops as a part-time or full-time occupation. Because they valued selfsufficiency, the Cutlerites also engaged in the trades and industries necessary to supply their daily needs, such as construction, carpentry, the manufacturing of wagons and farm implements,

43. C. Whiting, Manti Book Number One.

44. Federal Writers' Project of the Works Progress Administration for the State of Iowa, Iowa: A Guide to the Hawkeye State (New York, 1938), 430.

45. History of Fremont County, 485-500, lists the names of Cutlerites Rufus Fisher, William H. and Mark J. Chapman, Uriah Eggleston, Clark Stillman, Nelson A. Talcott, and Francis L. Whiting in various Iowa military units. 
MAP

SITES ASSOCIATED WITH THE CUTLERITES IN SOUTHWESTERN IOWA

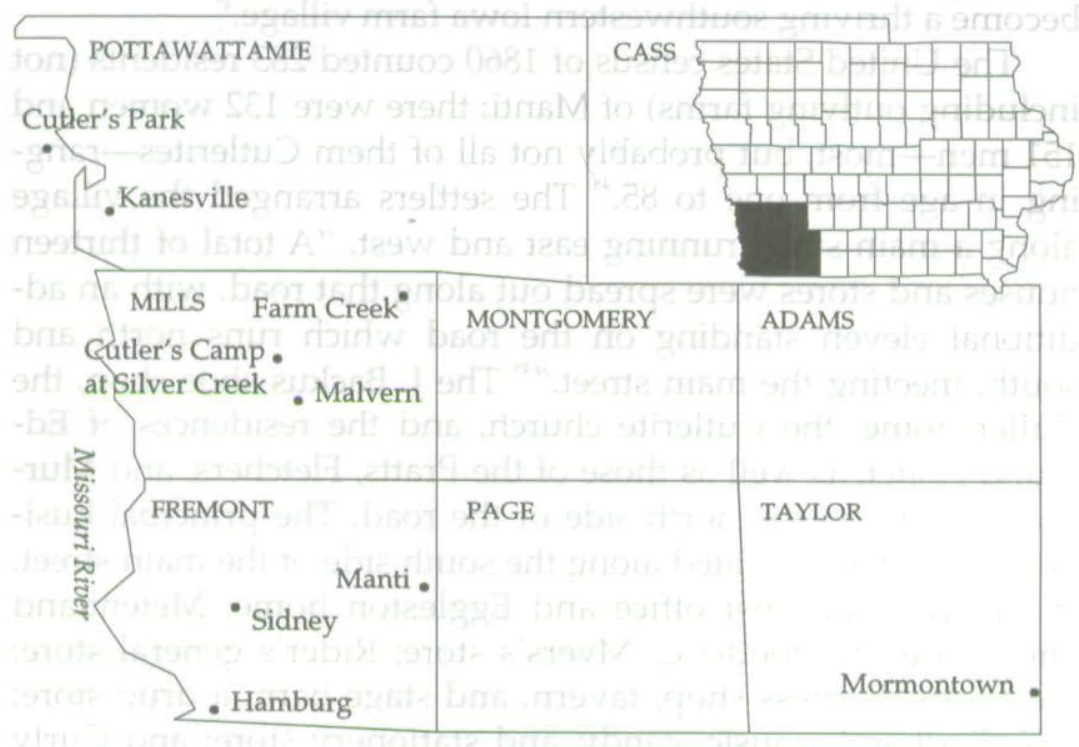

NOTE: County boundaries are shown as presently constituted. County boundaries were not permanently drawn at the time of the Cutlerite settlements.

blacksmithing, and furniture making. A log schoolhouse, erected in 1853, was probably the first public building at Manti. ${ }^{46}$

For subsequent construction, the Manti villagers hauled lumber from McKissick's Landing on the Missouri River south of present-day Hamburg, Iowa. In 1854 they built a frame structure for the newly organized Church of Jesus Christ at Manti. Their Sunday meetings drew rebaptized Cutlerites as well as current and former Latter-day Saints from at least a four-county area (Mills, Montgomery, Fremont, Page, and perhaps even Pottawattamie) of southwestern Iowa. Some of them occasionally traveled from as far away as Sidney, Hamburg, Malvern, and Farm Creek, Iowa, for weekend meetings and especially the spring and fall conferences of the main Cutlerite branch at Manti. The village of Manti became a United States mail stop beginning in 1856, and Amos Cox drove a coach on that line for a

46. See Fletcher and Fletcher, Alpheus Cutler, 55-59. 
while. Thereafter many non-Mormons, some of whom established professions and businesses, began settling at what had become a thriving southwestern Iowa farm village. ${ }^{47}$

The United States census of 1860 counted 283 residents (not including outlying farms) of Manti; there were 132 women and 151 men-most, but probably not all of them Cutlerites-ranging in age from one to $85 .^{48}$ The settlers arranged the village along a main street running east and west. "A total of thirteen houses and stores were spread out along that road, with an additional eleven standing on the road which runs north and south, meeting the main street." ${ }^{\prime 49}$ The J. Backus shoe shop, the Cutler home, the Cutlerite church, and the residences of Edmund Fisher, as well as those of the Pratts, Fletchers, and Murdocks, were on the north side of the road. The principal business district was located along the south side of the main street. It included the post office and Eggleston home; Metenhand and Crose dry goods; C. Myers's store; Rider's general store; the Scotts' harness shop, tavern, and stage barn; a drug store; J. R. Badham's music, candy, and stationery store; and Curly Stokes's blacksmith shop. The Whiting brothers-Almond, Sylvester, and Chancey-operated furniture making, wagon making, and clock and watch making businesses outside the main district; Hilbert Mcoughney owned a chair factory; and Russell Baldwin made caskets. William C. Matthews operated another tavern and stage barn called the Travellers Inn from the hillside west of the school. The villagers built a frame schoolhouse in 1869 to replace the log structure. The first teachers included R. W. Briggs, J. R. Badham, Rosetta Cox, Jennie Talcott, and Joe Wilcox.

THE CUTLERITES, after establishing themselves successfully at Manti, began thinking about expansion..$^{50}$ They intended to carry out Joseph Smith's plans to establish the Kingdom of God, and they remained committed to Lamanite ministries. On Sep-

47. Cunningham, ed., Manti.

48. 1860 U.S. Manuscript Census.

49. Latimer, The Manti Story, 3.

50. Fletcher and Fletcher, Alpheus Cutler, 59-61. 
tember 27, 1858, Cutler, in the company of Edmund Fisher and Hyram F. Pratt, scouted out a location for a colony. Five days later they identified a suitable site about fifty miles east of Manti on the Platte River in the northwest part of section twelve in present-day Jefferson Township in Taylor County. ${ }^{51}$ Over the next few years about a dozen Cutlerite families in Iowa relocated to the Taylor County site. The only known name of this settlement was Mormontown, as it was labeled by the non-Mormon residents of the area.

On this site the Cutlerite colonists built a few log dwellings along the river, and they established gardens, farm fields, and shops for blacksmithing as well as wagon construction. They also erected a flour mill on the Platte River. Their intent apparently was to establish a Cutlerite branch and community for the general purpose of building the Kingdom of God. The first mill (or mills) built by the Mormontown Cutlerites was repeatedly washed out by the flooding river, and a lack of financial resources strained the entire venture. The Cutlerites thereafter "went heavily in debt and built a steam mill, but 'Gentiles' [non-Mormons] were not eager to patronize the 'Mormons' and without their business, expenses and payments could not be met." The colonists became discouraged after "creditors took the mill, their cabins, and most all they had." ${ }^{152}$ Admitting failure, the Mormontown Cutlerites returned to Manti in 1865. By that time, however, the Cutlerite movement in Iowa had encountered other serious problems.

51. History of Taylor County, Iowa (Dallas, TX, 1981), 5-6. The location of this settlement was immediately west of present-day Blockton, near the bridge over the river.

52. Fletcher and Fletcher, Alpheus Cutler, 60. According to the History of Taylor County, Iowa, 5-6, 70, however, the Mormontown settlement continued even after the Cutlerites left. A post office, established at Mormontown on June 12, 1872 , continued until it was replaced by the Blockton post office on September 7,1887 . The town of Blockton grew up on the east bank of the Platte River southeast of the original settlement. In 1887 the Chicago Great Western railroad came through Mormontown. Several buildings, including a schoolhouse, were subsequently moved from Mormontown to Blockton. Except for the barely discernible remains of a mill at that location on the Platte River, almost nothing of Mormontown remains today. 
IN THE FALL OF 1849 (or spring 1850) the Latter-day Saint families of Samuel Badham, Augustus Richards, and others had founded a settlement at what came to be known as "Farm Creek. ${ }^{\prime 53}$ Some of these Saints already were or would soon become connected to Alpheus Cutler and his schismatic movement in several ways. Many of them knew the existing Cutlerite families from Nauvoo; some of them had been involved in the conflict between the Silver Creek Saints and the LDS High Council at Kanesville; and some of them were related to the Cutlerites by marriage and kinship. Eventually, a short-lived branch of the Cutlerite church was established at Farm Creek.

The Farm Creek settlement was located about three miles east of present-day Henderson in Mills County in the far southwestern corner of section one, range forty of Anderson Township. ${ }^{54}$ There the Latter-day Saints initially erected a few cabins along the west side of the creek. The Farm Creek settlement eventually consisted of a few homes, barns, and outbuildings along the creek and adjoining farmlands. There is no record of manufacturing or other industries and businesses beyond what was necessary for rural self-sufficiency. The settlers presumably supplied their needs by trade and commerce with the Manti Cutlerites or secular businesses located in the larger surrounding towns such as Glenwood and Kanesville. Other people, including former Mormons and non-Mormons, were attracted to these rich farmlands. The LDS portion of the community-Cutlerites as well as former and unaffiliated Mormons-comprised perhaps twenty to thirty households living on farms spread over a considerable territory around the heart of the settlement along the creek.

For nearly ten years after the settlers' arrival at Farm Creek, there apparently was not an organized LDS congregation there.

53. Fry, "History of Fremont (Iowa) District, Early Settlers, 1846," 345-59; Almon D. Hougas, "History of Farm Creek Branch," RLDS Library-Archives. According to the Mills County Tribune, 8 September 1908, August McClenahan, born in 1848, was the oldest native-born citizen of Mills County. His obituary further indicates that McClenahan was born "in the old town of Traders Point in the extreme northwest corner of the county. His parents came there in 1846." Two of August's sisters, Mrs. Daniel Hougas and Mrs. George Skank, were living near Henderson at that time.

54. Mills County, 25-27. 
Meetings were held irregularly in the homes of Mormons or former Mormons, while those who had become affiliated with or formally joined the Cutlerites sometimes traveled to Manti for weekend events, especially semiannual church conferences. According to James R. Badham, however, that situation changed in January 1858, when there was a Methodist revival in the Farm Creek area. ${ }^{55}$ Badham and many others from the area, excluding most of the current or former Latter-day Saints, were converted during the revival. Disturbed by his son's conversion, Samuel Badham, theretofore a Mormon, promptly announced a meeting of the Saints in his home.

According to J. R. Badham's account, Cutlerite Calvin Beebe Sr. was the speaker. "As the old brother unfolded the scriptures, explaining the fullness of the gospel, together with the necessity of being legally baptized," Badham recalled, "I drank it down as being that which seemed to be just what I wanted." Despite his previous conversion to Methodism, Badham reported being "convinced of the truth before the sermon was finished; and as soon as I could get to the speaker, I asked him if he had authority to baptize, and told him that I was ready." Shortly thereafter, Cutlerite elders Wheeler Baldwin and Squire Eggleston held additional meetings at Farm Creek. By March 1858, according to Badham, nearly all of the "Old Saints" (former Nauvoo Mormons) had joined the Farm Creek Cutlerite branch. Organized by Calvin Beebe, as the primary leader, along with Wheeler Baldwin and Squire Eggleston, it officially consisted of about forty members.

SINCE THE EARLY 1850s another group of Latter-day Saints, commonly known as Josephites, had been gathering up the (former) Saints scattered around the Midwest into an organization that later became the Reorganized Church of Jesus Christ of Latter Day Saints (RLDS). ${ }^{57}$ The Josephites, some of them already

55. J. R. Badham, "Experiences of J. R. Badham," Autumn Leaves 6 (1888), 167-72.

56. Badham, "Experiences," 168-69; Hougas, "History of Farm Creek Branch." 57. See Paul M. Edwards, Our Legacy of Faith: A Brief History of the Reorganized Church of Jesus Christ of Latter Day Saints (Independence, MO, 1991), for a sound historical overview of this movement. 
in dissent during the early 1840s, rejected Brigham Young's leadership and much of the novel Nauvoo Mormon theology. Many of them had become convinced that the founding prophet's eldest son, Joseph Smith III, was the rightful successor to prophetic leadership of the LDS religion. Informally known, therefore, as Josephites, they were able to persuade "Young Joseph" to accept prophetic leadership of this "new organization" in $1860{ }^{58}$

The Josephites had approached Alpheus Cutler in 1856 about joining their movement. Cutler rejected the overtures, rebuking them with claims of superior authority for the Latterday Saint Priesthood and Kingdom. ${ }^{59}$ Nevertheless, in 1859 Josephite missionaries William W. Blair and Edmund C. Briggs traversed "almost the entire State [of Iowa] on foot," seeking converts. After "suffering many privations and some sickness," they were welcomed into the home of Calvin Beebe Sr. at Farm Creek and invited to speak at a meeting that filled the two-room house of Newton Richards. That meeting was, by all accounts, warmed by many manifestations of the Spirit. ${ }^{60}$

Encouraged, Briggs and Blair proceeded to Manti, hoping to effect some reconciliation with Alpheus Cutler. ${ }^{61}$ Disappointed by the Manti Cutlerites' lack of interest, the missionaries returned to Farm Creek in September. Within days they baptized twenty-three members and organized a branch under the leadership of Calvin Beebe. ${ }^{62}$ Eventually most of the "old Mormon" families, including the Badhams, Beebes, Davises, Kelleys, and Richards, joined the RLDS, along with some members of local non-Mormon families who had intermarried with some of the Farm Creek Saints. At first this RLDS congregation held meet-

58. Roger D. Launius, Joseph Smith III: Pragmatic Prophet (Urbana, IL, 1988).

59. Zenas H. Gurley to Brother Cutler, 3 January 1856; Cutler to Gurley, 29 January 1856, both in RLDS Library-Archives.

60. Fry, "History ," 350-51; Badham, "Experiences," 171.

61. Memoirs of President W. W. Blair, 24.

62. Fry, "History," 350-51. This was the first RLDS branch in what became the Fremont District. Beebe was succeeded by Alexander Liles and later Samuel Badham. The branch declined after 1866, and it eventually disbanded. Several of the Farm Creek Saints, including Calvin Beebe, became prominent RLDS leaders. Edmund Kelley became a bishop, and his brother William later served as one of the RLDS Twelve Apostles. See Edmund G. Kelley, The Making of a Frontier Missionary (Independence, MO, 1980). 
ings in the Farm Creek schoolhouse. Later, they constructed a meetinghouse between the creek and the crossroads of what today are U.S. Highway 59 and County Road H-12. The Farm Creek cemetery, marking the graves of these Latter-day Saint pioneers in Iowa, is located less than a mile away on a small hill to the west along the creek.

Joseph Smith III, having assumed prophetic leadership of the RLDS movement in 1860, journeyed to Manti in 1862 (and again in 1863), accompanied by his brothers Alexander and David. He reportedly found "a group of quite able men" associated with Cutler. Smith noted that the Cutlerites "were so well organized that they stood by each other in every trial and adversity, and under every condition. Their credit was good in the towns and counties near them, especially so, I learned in Council Bluffs where they seemed to be well known in a business way." Yet Smith observed further that the Manti Cutlerites "had become imbued with the idea that God would soon command them to gather to Zion. So strong was this belief among them that they had made ready wagons, tents, and other appurtenances of nomadic life-and were ready, at a moment's notice, to throw their household goods into the vehicles and start for Independence [Missouri]."

In the early 1830s the Latter-day Saints had endeavored to build a city of Zion at Independence based on a revelation of the founding prophet, but they had been forcibly driven from that place in 1833-34. Later, in 1838-39, they had been forced to leave the state of Missouri entirely. Nevertheless, many of the Latter-day Saints, even in Utah but especially the Josephites and Cutlerites, still believed that Independence eventually would be the location, "the center place," of Zion, the Kingdom of God on earth. Any collective gathering of the Saints in Missouri was impossible, of course, during the 1860 s and perhaps even for some time thereafter. Previous resentments against the Mormons remained very much alive, and Missouri's culture was too closely aligned with the Confederate cause to provide any comfort for these former New Englanders or for any variety of Mormon.

63. Mary Audentia Smith Anderson and Bertha Audentia Anderson Hulmes, eds., Joseph Smith III and the Restoration (Independence, MO, 1952), 208. 
In spite of the Cutlerites' reservations about the Reorganization, they did permit young Joseph to preach twice in the Manti schoolhouse, but most of them were not impressed by the founding prophet's sons or their cause. Cutlerite Chancey Whiting, writing to his prominent Utah Mormon father-in-law, Isaac Morley, reported that Joseph and his brothers "had but little to say about their Father or their Father's work, scarcely mentioning the thing [building the millennial Kingdom of God as envisioned by Nauvoo Mormonism] at all." Whiting thought that their message was too universal: he noticed that, while "they gave good expectations," the Smiths "slipped easily over the grand principal strings of salvation, showing that they did not understand them [the Nauvoo salvation theology and related temple rites]." Whiting therefore "could not endorse with them," yet he noted that "a part of the people took up with it." Alpheus Cutler's failing health as he approached his eightieth year probably left some of his followers highly susceptible to the Josephites' overtures. By 1863 the aging leader was almost completely an invalid and barely able to speak understandably. ${ }^{64}$

Following up on the Smith brothers' visit, W. W. Blair returned to Manti in 1863, accompanied by William Redfield-a former Cutlerite and RLDS convert. In spite of Cutler's contempt for the Josephites, Blair "baptized seven to add to the nine baptized previously, and a strong, effective Reorganized Church branch [with about twenty-five attendees] was organized. ${ }^{\prime \prime 5}$ The Cutlerites were stunned by the defections, which included Thaddeus Cutler, Alpheus's eldest son and first counselor, and his spouse, Lemira, and probably their children; Luana Hart Beebe, Cutler's former plural wife, and their daughter, Olive; as well as some of the most prominent adult men, such as Wheeler Baldwin, Nicholas Taylor, William Topham, and William Matthews (and, most likely, members of their

64. Chancey Whiting to Isaac Morley, 13 December 1863, LDS Church Archives; Anderson and Hulmes, eds., Joseph Smith III, 207.

65. Pearl Wilcox, Roots of the Reorganized Latter Day Saints in Southern Iowa (Independence, MO, 1989), 212-13; Emma L. Anderson, "Others with the Church in an Early Day," Autumn Leaves 2 (1889), 494-95; idem, "History of the Cutlerite Faction of the Latter Day Saints," Journal of History (1895), 456. 
families). ${ }^{66}$ By $1864-65$, the Cutlerite movement in Iowa had been reduced to about 125 members.

\section{FOLLOWING YEARS OF POOR HEALTH, Alpheus Cutler} died at Manti on August 10, 1864. By that time, only about onefourth of those originally affiliated with the movement continued as active participants, but those remaining followers were exceptionally strong in the faith. They exhibited a powerful resolve hardened by failures and disappointments, and they were fully dedicated to Cutlerism and its future success, especially its Indian ministries, in spite of previous failures. Yet the Cutlerites were also extremely apprehensive about the rival Josephites and the possibility of further involvement in the Civil War. ${ }^{67}$

Raiders from Missouri and Kansas had ventured periodically into Iowa, destroying property and sometimes killing citizens. ${ }^{68}$ The Cutlerites, most of them descended from Yankee families, were ardent abolitionists. Yet they felt little obligation to a federal government that they believed had repeatedly failed to protect their rights and property as Latter-day Saints over the preceding twenty years. Many of the founding generation of Cutlerites proudly claimed American war veteran ancestors, but they had also experienced severe persecution as Mormons. Twice in Missouri and once in Illinois, many of them had watched helplessly as their homes and farms were burned by

66. Herman Hale Smith, "The Mormons in Iowa," unpublished MS, 1929, RLDS Library-Archives; idem, The History of the Reorganized Church of Jesus Christ of Latter Day Saints, 4 vols. (Independence, MO, 1973), 3:323.

67. Fletcher and Fletcher, Alpheus Cutler, 61-63.

68. "Missouri and its border lands was a hot-bed of secession and civil strife, and the Cutlerites, who were strong anti-slavery sentiment, suffered many depredations at the hands of their neighbors. Partly for this reason and partly because of religious persecution the Cutlerites felt that they would enjoy greater liberty and freedom if they should move to Minnesota." Alta Kimber, "Settlement of Latter Day Saints in Otter Tail County," unpublished MS, 1933, Otter Tail County Historical Society, Fergus Falls, MN, 2. According to Cutlerite Sylvester Whiting, a party of soldiers cut down the "peace" flag flown by the Cutlerites at Manti, "and so added another crime to their damnable deeds, it cost at least $\$ 100.00$ to make." Quoted in Edna Fletcher, ed., "A Brief Sketch of the History of the True Church of Jesus Christ (Cutlerites), As Taken from the Written Records of Those That Knew," unpublished mimeograph, 1960, in possession of the author, 3 . 
non-Mormon neighbors. Furthermore, most of them had lost loved ones in those armed conflicts or subsequent hardships. A few of the young Cutlerite men volunteered and fought with the Union armies. Some of them also enlisted in the Iowa Border Guard. Yet the Cutlerites collectively were apprehensive about any further direct involvement in the Civil War.

Even before their leader's death, the Cutlerites had seriously considered leaving Iowa, if not for building Zion at Independence, Missouri, then somewhere else, away from the Josephites and the war. Increasingly, they came to believe in a prophecy attributed to Cutler that they would ultimately find a secure home to the north. "Father Cutler had told us many times of a place he had seen in a vision; had spoken of the lake and grass, and we, as a church had long expected to move there. ${ }^{\prime \prime 9}$ Cutler's death provided the catalyst for action. "Father [Pliny] Fisher told us in the gift of tongues," Sylvester Whiting reported, "that the time would soon come that we could live on wheels and to take care of our wagon covers for we would need them, and also we would go to a place of many waters. Mrs. Sherman, by the gift of tongues, said the Lord always led his people out of danger, and when we see danger on all sides but one, we should flee out." ${ }^{\prime 70}$ The Cutlerites also believed that moving to the wilds of Minnesota might enable them to renew Cutler's previous commitment to Indian ministries.

Even so, the determination by some of the Cutlerites to relocate north to Minnesota was controversial, and the controversy was aggravated by the lack of a primary leader. Unable to decide the leadership question, they shelved it temporarily. ${ }^{71}$ The Iowa Cutlerites and Josephites had been divided bitterly by different interpretations of the Latter-day Saint religion, but they also were tied together by powerful bonds of kinship. The Josephite kinfolk opposed leaving Iowa, citing a prophecy by

69. Mrs. Isaac [Sarah Jane, known as Jennie] Whiting, "Memories," in Hallie Gould, ed., Old Clitherall's Story Book: A History of the First Settlement in Otter Tail County, Minnesota, 1865-1919 (Fergus Falls, MN, 1919), 8-9.

70. S. J. Whiting, "Some proofs and testimonies in regard to our move to this county being directed by the Lord," unpublished MS, n.d., Otter Tail County Historical Society, Fergus Fall, MN, 1.

71. Fletcher and Fletcher, Alpheus Cutler, 69. 
young Joseph that promised that they would be blessed and prosper if they would develop and expand their fertile farms in southwestern Iowa. ${ }^{72}$ Consequently, for many of the Cutlerites, migrating to Minnesota meant exacerbating religious differences with Josephite kin through tremendous geographical separation. Either decision, to leave or to remain in Iowa, held unfavorable consequences.

Eventually the Cutlerite High Council agreed to send a small expedition to scout out prospects in Minnesota. Authorization of the expedition represented an implicit compromise. It satisfied those who wanted to move, and it allowed othersCutlerites and perhaps Josephite kinfolk, too-additional time to make a final decision. Chancy Whiting-Alpheus Cutler's eventual successor-observed retrospectively that "some divisions arose relative to the rights of authority; the church became measurably broken up and it was thought advisable to sell our farms and remove to Minnesota." ${ }^{173}$

BY SEPTEMBER 29, 1864, the Cutlerites' exploratory party was ready to depart Manti. Because it was late in the year, the group anticipated blazing a trail, locating a site for settlement, planting crops, and making other preparations for later arrivals. The expedition, led by Lewis Denna, traveled north to Red Wing, where they wintered, and then northwest to Otter Tail County, Minnesota. ${ }^{74}$ There, between two lakes, they founded the village of Clitherall, the first permanent Euro-American settlement in

72. Having seen the fertile farmland in Iowa and conjecturing its enhanced value with the anticipated coming of the railroad, Smith reported, "Right then and there I was moved to utter publicly a prophecy, which I believe was given under the influence of the Spirit. ... In the name of the Master I counseled them, pledging my reputation for the success of the venture, to secure a foothold upon all the lands thereabout which they could possibly and honestly get into their possession, and then hang onto them." Anderson and Hulmes, eds., Joseph Smith III, 209.

73. Gould, ed., Old Clitherall's Story Book, 12.

74. Emma L. (Whiting) Anderson, “Autobiography: Reminiscences, 1853-1920," RLDS Library-Archives; Danny L. Jorgensen, "North from Zion: The Minnesota Cutlerites, 1864-1964," paper presented to the Mormon History Association, St. George, UT, May 1992. 
the region. ${ }^{75}$ Two migrant parties of Iowa Cutlerites followed in 1865. Over the next several years a few additional Iowa families joined their friends and relatives in Minnesota, while some Cutlerite families living there returned to Iowa. All of the Cutlerites who stayed in Iowa eventually joined the Josephites, became inactive, or in a few instances moved to Utah or affiliated with local Protestants. Hence, by 1865, the Church of Jesus Christ (Cutlerite) was permanently removed from Iowa.

Almost all remains of the Latter-day Saint encampment on Silver Creek have vanished from the landscape. Some of the graves from the Saints' cemetery were relocated to the top of the hill at the East Liberty church and cemetery, but few of them are marked today. A trail marker was recently erected near the original site of the Silver Creek camp. The Cutlerite community at Farm Creek never developed into anything more than a collection of houses and barns. What remains of the RLDS meetinghouse at the crossroads is now used as a hog barn. To the west toward Henderson, along a gravel road, the nicely maintained Farm Creek Cemetery still sits unobtrusively on the small hill. The weather-worn grave markers of these Latter-day Saint pioneers, some of them imprinted with Book of Mormon names, are about the only other physical reminder of what transpired there about 150 years ago.

Some of the local residents of Blockton still proudly recall the founding story of Mormontown, but otherwise there is little discernible trace of the Cutlerite colony on the Platte River today. The once thriving frontier village of Manti declined when the railroad passed it by, resulting in the development of Shenandoah. Today, about two miles south of Shenandoah, a cottage,

75. Fletcher and Fletcher, Alpheus Cutler, 63-73; Kimber, "Settlement of Latter Day Saints in Otter Tail County"; idem, "The Coming of the Latter Day Saints to Otter Tail County," Minnesota History 13 (1932), 385-94; Hallie M. Gould, "Like Sheep that Went Astray: Concerning the 'Cutlerite' Faction of the Church that went north during the 'dark and cloudy day," Autumn Leaves 34 (1921), 49-56; Gould, ed., Old Clitherall's Story Book; Biloine W. Young, "Minnesota Mormons: The Cutlerites," Courage 3 (1973), 117-37; John W. Mason, ed., History of Otter Tail County, Minnesota: Its People, Industries, and Institutions (Indianapolis, 1916), 40-43. The Sioux uprising had killed or cleared most of the previous American settlers from western Minnesota in 1862, so Clitherall was the first permanent Euro-American settlement in Otter Tail County. 
house, and barn mark the former main street (now a gravel country road) at Manti. The inn and stage barn still stand on the hill, around a curve in the road, to the west; and the foundation of the schoolhouse is observable along Fisher's Creek. The old hickory grove on the hill is now a park which contains a restoration of the Cutlerite cemetery at the top of the hill. ${ }^{76}$ Some of the history of the Cutlerite settlement at Manti and a variety of artifacts from its early period are preserved at the Shenandoah Historical Museum today.

The most vital and enduring legacy of these Latter-day Saint and Cutlerite pioneers are the descendants of those who stayed in Iowa." Many of them contributed immeasurably to the growth of the RLDS church-particularly at Farm Creek, Shenandoah, and nearby communities-which continues to influence the history of Iowa and the region. ${ }^{78}$ Some of their descendants, furthermore, can be counted among those who have made a variety of important contributions to the history of southwestern Iowa. They successfully established farms, businesses, and small industries, became schoolteachers, or pursued professional careers in law and medicine, and many of them have participated fully in the civic life of the communities and counties across southern Iowa.

76. Over the years, many of the original grave markers were removed, used for other purposes (such as stepping stones), or scattered over the area. Some of the markers were subsequently found and restored to the approximate location, but not exact grave sites, of the original Cutlerite cemetery on the hill.

77. The Josephite missionaries followed the Cutlerites to Minnesota in the 1870 s and converted many of the younger members. By the 1920s, most of the younger people who remained Cutlerites had moved and founded a second branch of the church at Independence, Missouri. They still own a meetinghouse, cemetery, and other property around Clitherall, Minnesota, today. Some of them travel to Clitherall for the summer and hold Sunday meetings, but only one Cutlerite resides in Minnesota today. The Cutlerite church in Missouri is sustained by fewer than a dozen active members today. They nevertheless believe that, according to a prophecy attributed to Father Cutler, a mighty leader eventually will rescue and revitalize the Cutlerite church.

78. The RLDS church is sustained by many strong congregations across Iowa. Graceland College at Lamoni, which is owned and operated by the RLDS, is a unique Iowa asset. See Paul M. Edwards, The Hilltop Where . . . : An Informal History of Graceland College (Lamoni, 1972). 
Copyright of Annals of Iowa is the property of State of Iowa, by \& through the State Historical Society of Iowa and its content may not be copied or emailed to multiple sites or posted to a listserv without the copyright holder's express written permission. However, users may print, download, or email articles for individual use. 